\title{
Interaction between audiology and genetics in the study of a family: the complexity of molecular diagnosis and genetic counseling
}

Flavia Maria Rodrigues Hoffmann', Patrícia Fernandes Rodrigues ${ }^{2}$, Teresa Maria Momensobn dos Santos $^{3}$, Edi Lucia Sartorato ${ }^{4}$, Andréa Trevas Maciel-Guerra ${ }^{5}$, Carla Gentile Matas ${ }^{6}$, Vanessa Cristine Sousa de Moraes ${ }^{7}$
Keywords: counseling, hearing loss, genetics, mutation.

\section{Summary}

$\mathrm{H}$ earing loss is a multifaceted condition with many etiologies, among which genetic mutation is. Therefore, it is important to connect audiological investigation to etiological diagnosis. Aim: this study aims to establish the audiological and genetic profiles of three non-syndromic children with sensorineural hearing loss. Materials and method: three brothers aged 3, 5 and 16 were enrolled in this study. They were submitted to behavioral and electrophysiological hearing tests and molecular studies. Results: the hearing tests showed moderate to moderately severe bilateral symmetric sensorineural hearing loss and an accentuated descending slope. Transient and Distortion Product Otoacoustic emissions were absent in the two younger children. ABR showed a bilateral moderately severe to severe sensorineural hearing loss. P300 showed bilateral normal latencies in the older brother. Molecular tests showed that the two younger children were heterozygote for mutation 35delG on gene GJB2. Conclusion: The combination of speech and hearing tests and genetic analysis allows for the etiologic diagnosis of seemingly similar hearing loss cases, which however display different genetic backgrounds. Molecular studies must be comprehensive enough to avoid precipitated diagnosis which may impair genetic counseling.

\footnotetext{
${ }^{1}$ Specialist in audiology at Instituto de Estudos Avançados da Audição, IEAA, Brazil. Speech and Hearing Therapist.

${ }^{2}$ PhD in Human Communication Disorders, Speech and Hearing Therapy at Universidade Federal de São Paulo, UNIFESP, Brazil. Speech and Hearing Therapist, Professor in the specialization program on Audiology at Instituto de Estudos da Audição - IEAA.

${ }^{3} \mathrm{PhD}$ in Human Communication Disorders, Speech and Hearing Therapy at Universidade Federal de São Paulo, UNIFESP, Brazil. Speech and Hearing Therapist, Full Professor at PUC SP, Director at Instituto de Estudos Avançados da Audição - IEAA.

${ }^{4} \mathrm{PhD}$ in Genetics and Molecular Biology at Universidade Estadual de Campinas, UNICAMP, Brazil. Researcher at Centro de Biologia Molecular e Engenharia Genética da UNICAMP, Associate Professor of Medical Genetics at UNICAMP.

${ }^{5} \mathrm{PhD}$ in Genetics and Molecular Biology at Universidade Estadual de Campinas, UNICAMP, Brazil. MD, Geneticist, Full Professor at the Medical Genetics Department at Faculdade de Ciências Médicas da UNICAMP.

${ }^{6} \mathrm{PhD}$ in Human Communication Disorders, Speech and Hearing Therapy at Universidade Federal de São Paulo, UNIFESP, Brasil. Adjunct Professor in the Speech and Hearing Therapy program at the Department of Physiotherapy, Speech and Hearing Therapy, and Occupational Therapy at Faculdade de Medicina da USP. ${ }^{7}$ Biologist. Scholarship holder on Technical Training at FAPESP's Centro de Biologia Molecular e Engenharia Genética. IEAA - Instituto de Estudos Avançados da Audição

Send correspondence to: Flávia Maria Rodrigues Hoffmann - Rua Coronel Airton Gonçalves Froes 196 Jd. São Cristóvão Bragança Paulista SP $12906-040$. Tel. (0xx11) 4033-4066

This paper was submitted to the RBORL-SGP (Publishing Manager System) on 17 May 2007. Code 4530.

The article was accepted on 25 February 2008.
} 


\section{INTRODUCTION}

Hearing loss (HL) is the most frequently diagnosed sensorial deficit. This condition impairs the exertion of communication skills ${ }^{1}$ and introduces a series of social, psychical, and educational hurdles to those affected by it. When diagnosed by the first year of life, medical and speech and hearing therapy approaches can be devised to critically act on a still maturing and more plastic central nervous system, thus improving the global prognostic possibilities of the involved child ${ }^{2}$.

Behavioral and electrophysiological tests are available to assist with the audiological diagnosis, and may be used as part of the assessment procedure ${ }^{3-11}$. Test applicability is based on patient maturation and development status.

Congenital sensorineural hearing loss may or not have a genetic background. Within the geneticallyoriginated cases, there are those in which HL is part of a syndrome (30\%) and those in which it is an isolated condition - non-syndromic sensorineural HL $(70 \%)^{12-14}$. Over 100 genes are potentially involved in non-syndromic prelingual $\mathrm{HL}^{14}$, which originates in $85 \%$ of the cases from recessive autosomal inheritance, in $12 \%$ to $14 \%$ from dominant autosomal inheritance, and in $1 \%$ to $3 \%$ is bound to chromosome $\mathrm{X}^{15,16}$.

Within the cases of non-syndromic recessive autosomal inheritance HL are the ones occurring from mutations on gene GJB2, in charge of encoding protein conexin 26. One of these mutations, 35delG, accounts for about $70 \%$ of the mutant alleles in European and NorthAmerican Caucasians, with $2.3 \%$ to $4 \%$ heterozygotes ${ }^{17-20}$. In Brazil, the heterozygote frequency of mutation 35delG is estimated at 1:7421. Other genetic alterations found in non-syndromic HL patients are deletions on the gene connected to conexin 30 (GJB6-Cx30), del (GJB6 - D13S1830) and del (GJB6 - D13S1854), as well as mutation A1555G on mitochondrial gene 12SrRNA ${ }^{22-24}$.

In developing countries environmental factors such as congenital infections and perinatal disorders are still quite common ${ }^{25}$. However, as health care to mothers and infants improves, the relative frequency of genetic-origin cases progressively increases ${ }^{26}$.

In cases of genetically-acquired hearing loss, additionally to early auditory stimulation and use of hearing aids, genetic counseling must also be considered to allow individuals and their families to make well-informed decisions on procreation ${ }^{27}$. Gene therapy is still being researched, and cannot be applied in every situation ${ }^{28}$.

Genetic counseling for cases of inherited nonsyndromic HL relies heavily on accurate diagnosis of the inheritance mechanism. The introduction in Brazil of tests to check for mutation 35delG on gene GJB2, among other exams required to clarify the etiology of the condition has been fundamental for effective genetic counseling. Indeed, its detection is highly relevant in tracking the origins of $\mathrm{HL}$, thus reinforcing the relevance of having comprehensive molecular to avoid precipitated diagnosis and unnecessary stress for the families.

This paper aims to report on the audiological profiles and genetic test results of a family from the municipality of São Paulo, emphasizing the genetic heterogeneity of HL patients and the complexity of genetic counseling.

\section{MATERIALS AND METHOD}

This study was approved by the Research Ethics Committee at CEFAC under permit 172/05.

The index-case (II.5, Fig. 1), male, HL patient, was seen for the first time when he was 16 at the Clinical Audiology ward at IEAA in November of 2004, after his speech and hearing therapist asked him to undergo audiological examination. He was the second of four children of a non-consanguineous couple. The family consisted of a 41-year-old mother (I.2), a 40-year-old father (I.3), an older 17-year-old sister (II.4) with hearing sensitivity within normal standards who had a one-year-old son (III.2), and two younger brothers of five (II.6) and three years of age (II.7) respectively, both with hearing loss. There was also an older, 21-year-old half-sister (II.2) from the mother's side also with normal hearing, with a one-year-old daughter (III.1). The three affected siblings had prelingual non-progressive HL.

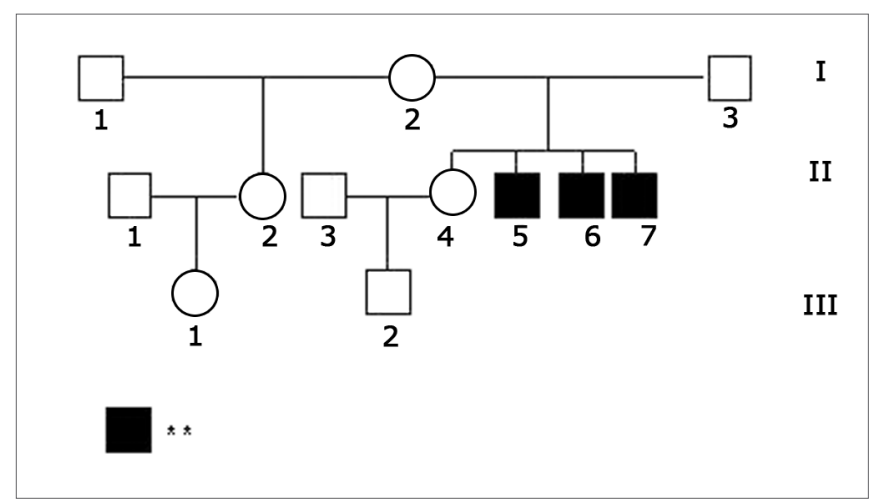

Figure 1. Inheritance patterns of the family analyzed in this study. Legend: ** Hearing loss.

\section{Audiological examination}

Audiological examination included both behavioral and electrophysiological tests, conducted based on the needs of each participant considering their ages and presence of hearing impairment.

Tone audiometry (TA), speech audiometry (SA), impedance tests (IT), acoustic reflex measurements (ARM), 
distortion product otoacoustic emission (DPOAE) tests, and transient-evoked otoacoustic emission (TEOAE) tests were conducted at the IEAA.

Brainstem auditory evoked potential (BAEP), middle-latency auditory evoked potential (MLAEP), and P300 tests were conducted at the CDP at FMUSP. Chart 1 shows the audiological findings for all family members.

\section{Molecular studies}

Genetic tests were carried out at the Center for Molecular Biology and Genetic Engineering at UNICAMP.
Presence of mutation 35delG on gene GJB2 was investigated using *AS-PCR (allele-specific polymerase chain reaction) to discriminate normal from mutant alleles, thus telling normal homozygotes from 35delG homozygotes and mutated heterozygotes; this gene was also completely sequenced.

Deletions involving the conexin 30 gene (GJB6Cx30) were also analyzed - del (GJB6 - D13S1830) and del (GJB6 - D13S1854) - using multiplex PCR; mutation A1555G on mitochondrial gene 12SrRNApor was searched through restriction analysis with digestion of enzyme Bsm AI.

Chart 1. Audiological test results per subject.

\begin{tabular}{|c|c|c|c|c|c|c|c|c|c|}
\hline Subject & TA & SA & IT & ARM & DPOAE & TEOAE & BAEP & MLAEP & P300 \\
\hline 1.2 & $x$ & $x$ & $x$ & $x$ & - & - & - & - & - \\
\hline 1.3 & $x$ & $x$ & $x$ & $x$ & - & - & - & - & - \\
\hline II.2 & $x$ & $x$ & $x$ & $x$ & - & - & - & - & - \\
\hline II. 4 & $x$ & $x$ & $x$ & $x$ & - & - & - & - & - \\
\hline II.5 & $x$ & $x$ & $x$ & $x$ & $x$ & $x$ & $x$ & $x$ & $x$ \\
\hline II. 6 & $x$ & $x$ & $x$ & $x$ & $x$ & $x$ & $x$ & - & - \\
\hline II. 7 & $x$ & $x$ & $x$ & $x$ & $x$ & $x$ & $x$ & - & - \\
\hline III.1 & $x$ & $x$ & $x$ & $x$ & - & $x$ & - & - & - \\
\hline III.2 & $x$ & $x$ & $x$ & $x$ & - & $x$ & - & - & - \\
\hline
\end{tabular}

\section{RESULTS}

Audiological evaluation of the index-case (II.5) and siblings (II.6 and II.7) showed an audiometric curve with sensorineural bilateral symmetric hearing loss, with an accentuated descending configuration. Individuals II.5 and II.7 had moderately severe bilateral hearing impairment and II.6 had moderate hearing loss in the right ear and moderately severe HL on the left ear. The parents (I.2 and I.3), sister (II.4), half-sister (II.2) and nephews (III.1 and III.2) had normal hearing thresholds. DPOAEs were absent on II.6 and TEOAEs were absent on subject II.7.

BEAP test results were consistent with severe bilateral hearing loss for clicks on subjects II. 5 and II.7 and moderately severe on II.6. P300 showed latencies within normal range bilaterally for subject II.5.

In terms of molecular tests, none of the analyzed individuals had deletions in the conexin 30 gene or mutations on gene 12SrRNA. Mutation 35delG in heterozygosis was found in the index-case mother's (I.2) gene GJB2, in the older sister (II.4) with normal hearing and in the two siblings with hearing impairment (II.6 and II.7). The father (I.3), the index-case (II.5) and the half-sister's daughter (III.1) are normal homozygotes, and thus did not have mutation 35delG; unfortunately it was not possible to perform molecular tests on the half-sister (II.2) and the nephew (III.2). Molecular findings can be seen in the inheritance patterns shown in Figure 2.

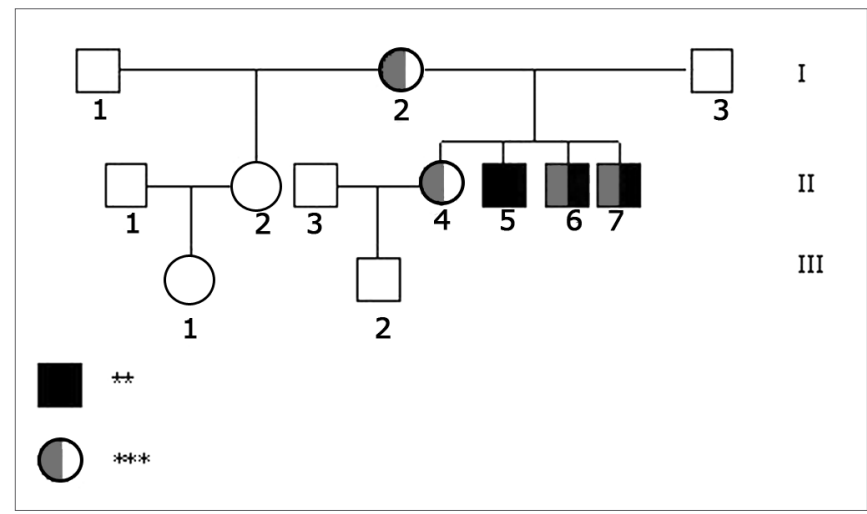

Figure 2. Family inheritance patterns showing genetic test results. Legend: ** Hearing loss *** Heterozygote 35 delG N - Normal allele NR - Not realized.

\section{DISCUSSION}

Hearing impairment introduces a series of restrictions and difficulties into the lives of those affected by it ${ }^{1}$. Early diagnosis is crucial in offering patients the best intervention possible ${ }^{2}$, as is an effective interaction between speech and hearing therapy and genetics.

The thorough audiological examination performed with the core of the family (parents and siblings) added to the tests done with the half-sister and the nephews revealed that the three siblings had practically the same kind of 
hearing loss, and that their parents, sister, half-sister and nephews had normal hearing ${ }^{3-11}$.

The study also showed that the identified hearing impairment was of the sensorineural prelingual nonsyndromic type ${ }^{12-14}$.

Many are the possible inheritance mechanisms ${ }^{15,16}$ at play, the most likely being the recessive autosomal, in which the normal parents do not present the phenotype, are heterozygote carriers, and have the disorder manifesting itself in their offspring; another possibility is a recessive inheritance pattern connected to chromosome X, with a normal phenotype heterozygote carrier mother with the disorder affecting only male individuals.

It is still possible to consider dominant autosomal inheritance, with incomplete penetrance in one of the parents or consequent to germinative tissue mutation in one of them ${ }^{15,16}$, and maternal or mitochondrial inheritance ${ }^{24}$, with preferential clinical manifestation in males, as is the case in Leber's optic neuropathy.

The limitations related to the diagnosis of patients with non-syndromic sensorineural hearing loss through molecular tests pose an interesting challenge. If the genetic tests had been limited to one of the siblings carrying mutation 35delG (II.6 and II.7) and one of the parents, we would have looked at explaining the presence of the mutation in heterozygosis in individuals with hearing loss. Indeed, one of the biggest difficulties in offering genetic counseling to individuals carrying mutations in the conexin 26 gene - including mutation $35 \mathrm{delG}$ - is the fact that in $10 \%$ to $40 \%$ of the cases these mutations are detected only in one of the alleles, but still result in hearing loss. In some cases these mutations segregate with deletions in gene GJB6, i.e., the individual is heterozygote for mutations in gene GJB2 and in the other allele he or she presents one of the two deletions involving gene $\mathrm{GJB} 6^{22,23}$. In the family we analyzed, however, no such deletions were found. In monoallelic cases with mutation in gene GJB2, it is not possible to exclude interactions between mutations in the conexin 26 gene and in other genes related to hearing loss in a digenic inheritance pattern. Another possibility to explain this situation is the presence of modifier genes with dominant negative effect upon the normal allele, which in this case would depend on the genetic background of each individual.

Still in reference to the scenario in which subject II.5 did not undergo molecular testing, any geneticist would see as the best possibility a situation in which the interaction occurred in the other allele is not explained, and thus mutation 35delG would be connected to the hearing loss phenotype presented by the family.

Therefore, recessive inheritance connected to chromosome X could be excluded and thus the risk of the sister (II.4) and the half-sister (II.2) having male children with hearing loss would not be considered, as nor would mitochondrial inheritance, thus also discarding the risk for the offspring of the sister and that of the half-sister.

However, as the core of the family was entirely studied, we could verify that the hearing loss phenotype is independently segregated from genotype $35 \mathrm{del}$. Indeed, there were two individuals carrying the mutation with yet normal hearing (I.2 and II.4) and one with hearing loss but without mutation 35delG (II.5).

Mutation 35delG can thus be considered to be a casual finding, given the fact that this mutation in heterozygosis is quite common within the unaffected, getting to as much as $4 \%$ in some populations ${ }^{17-2} 1$. All possibilities initially considered to explain the inheritance mechanism remain valid, thus making it impossible to accurately calculate the risk of recurrence of the impairment in the family and thus compromising any genetic counseling effort.

\section{CONCLUSION}

This paper stresses the importance of multidisciplinary diagnosis and the need of establishing closer ties between speech and hearing therapy and genetics to enhance the etiologic diagnosis and genetic counseling offered to hearing loss cases.

\section{REFERENCES}

1. Godinho R, Keogh I, Eavey R. Perda Auditiva Genética. Rev. Bras. Otorrinolaringol. [online]. Jan./Fev. 2003, vol. 69, no. 1 [cited 06 Novembro 2005], p. 100-104. Available from World Wide Web: http:// www.rborl.org.br/conteudo/acervo/print_acervo.asp?id=35. ISSN 1806-9312.

2. Azevedo MF. Avaliação audiológica no primeiro ano de vida. In: Lopes Filho, OC (org.). Tratado de Fonoaudiologia. São Paulo, Editora Roca Ltda.; 1997, cap. 11 p.239-63.

3. Russo ICP, Santos TMM. A Prática da Audiologia Clínica. São Paulo: Cortez editora; 2005.

4. Granato L, Pinto CF, Ribeiro MQ. Perda Auditiva de Origem Genética. In: Lopes Filho OC (org.). Tratado de Fonoaudiologia. São Paulo: Editora Roca; 1997 , cap. 2 p. 25-53

5. Pfeilsticker LN, Stole G, Sartorato EL, Delfino D, Maciel-Guerra AT. Genetic investigation of non-syndromic hereditary deafness. Rev Bras Otorrinolaringol 2004; 70: 182-6.

6. Petit C. Genes responsible for human hereditary deafness: symphony of a thousand. Nature Genet 1996:14:385-91.

7. Van Camp V, Willems PJ, Smith RJH. Non-syndromic hearing impairment: unparalleled heterogeneity. Am J Hum Genet 1997:60:75864.

8. Estivill X, Fortina P, Surrey S, Rabionet R, Melchionda S, DÁgruma L, et al. Connexin-26 mutations in sporadic and inherited sensorineural deafness. Lancet 1998; 351: 394-8.

9. Antoniadi T, Rabionet R, Kroupis C, Aperis GA, Economides J, Petmezakis J, et al. High prevalence in the Greek population of the 35 delG mutation in the connexin 26 gene causing prelingual deafness. Clin Genet 1999; 55(5):381-2.

10. Green GE, Scott DA, McDonald JM, Woodworth GG, Sheffield VC, Smith RJ. Carrier rates in the midwestern United States for GJB2 mutations causing inherited deafness. JAMA. 1999 ; 281(23):2211-6.

11. Storm K, Willcox S Flothmann K, Van Camp G. Determination of the carrier frequency of the common GJB2 (connexin-26) 35delG mutation in the Belgian population using an easy and reliable screening method. Hum Mutat 1999; 14(3):263-6 
12. Oliveira CA. Determinação da freqüência dos alelos 35 delG no gene da conexina $26 \mathrm{em}$ amostras da população brasileira. Campinas, 2005. [Tese de doutorado curso de Ciências Biomédicas, Faculdade de Ciências Médicas - UNICAMP].

13. Piatto VB, Bertollo EMG, Sartorato EL, Maniglia V. Prevalence of GJB2 mutations and the del(GJB6-D13S1830) mutation in Brazilian patients with deafness. Hearing Research. 2004; 196: 87-93

14. Del Castillo FJ, Rodriguez-Ballesteros M, Alvarez A, Hutchin T, Leonardi E, Oliveira CA, et al. A novel deletion involving the connexin-30 gene, Del(GJB6-d13s1854), found in trans with mutations in the GJB2 gene (connexin-26) in subjects with DFNB1 non-syndromic hearing impairment. J Med Genet. 2005; 42(7):588-94.

15. Prezant TR, Agapian JV, Bohlman MC, Bu X, Oztas S, Qiu WQ, et al. Mitochondrial ribosomal RNA mutation associated with both antibiotic-induced and non syndromic deafness. Nat Genet 1993; 4 : 289-94.

16. Neto JFL, Pereira AC. O que há de Novo no Campo da Genética Molecular da Surdez: Descoberta de Genes para Surdez. Rev Bras Otorrinolaringol[online]. Mar/Abr 1999; (65)2 [cited 06 Outubro 2005], p. 106-113. Available from World Wide Web: http://www.rborl.org. br/conteudo/acervo/print_acervo.asp?id=1452. ISSN 1806-9312.

17. Sartorato EL. A genética da surdez. Pesquisa Fapesp, janeiro/fevereiro 2000, p.26-28.
18. Ramalho AS. As hemoglobinopatias hereditárias: Um problema de Saúde Pública no Brasil. Ribeirão Preto, Editora da Sociedade Brasileira de Genética; 1986. p. 119-28.

19. Faria I. Perda auditiva de origem genética: uma retrospectiva da literatura. São Paulo, 2001. [Monografia de Especialização em Audiologia clínica - Cediau].

20. Lloyd LL, Kaplan H. Audiometric interpretation: a manual of basic audiometry. Baltimore: University Park Press; 1978.

21. Carhart R. An improved method for classifying audiograms. Laryngoscope 1945;55:640.

22. Silman S, Silverman CA. Auditory Diagnosis - Principles and Applications. San Diego-London: Singular Publishing Group; 1997.

23. Lopes Filho OC, Carlos RC. Emissões Otoacústicas. In: Lopes Filho, OC (org.). Tratado de Fonoaudiologia. São Paulo: Editora Roca; 1997. cap.10 p. 221-37.

24. Manual do usuário - Ero Scan - Etymotic Research; 1999.

25. Manual do equipamento Biologic - Evoked Potential User Manual BIO -LOGIC; 1998

26. Musiek FE, Lee WW. Potenciais auditivos de média e longa latência - In: Perspectivas Atuais em Avaliação Auditiva - Org. Musiek FE, Rintelmann WF. Barueri, São Paulo: Editora Manole; 2001. p.23967.

27. McPherson DL. Late potentials of the auditory system (evoked potentials). San Diego: Singular Press; 1996. 